Jurnal Pendidikan Indonesia Gemilang, Vol 1, No.1, 2021, pp. 7-12

e-ISSN 2807-5285. DOI. 10.53889/jpig.v1i1.18

\title{
Upaya Meningkatkan Hasil Belajar Seni Budaya Siswa Kelas IX melalui Model Project Based Learning
}

\author{
Disubmit 11 Juli 2021, Direvisi 24 Agustus 2021, Diterima 30 Agustus 2021 \\ Heri Kusnawan ${ }^{1 *}$ \\ ${ }^{1}$ SMP Negeri 1 Citeureup, Kabupaten Bogor, Indonesia \\ Email Korespondensi: *herikusnawan1965@gmail.com
}

\begin{abstract}
Abstrak
Tujuan penelitian ini adalah untuk mengetahui penerapan model project based learning dalam meningkatkan hasil belajar seni budaya siswa. Indikator hasil belajar siswa yang digunakan dalam penelitian ini diantaranya adalah; dapat mengeksplore, mendesain, dan mempublikasikan/memamerkan karya seni musik recorder. Penelitian ini dilakukan di kelas IX di salah satu SMP Negeri di Kabupaten Bogor, Indonesia. Penelitian ini dilakukan dengan mengambil 2 siklus penelitian, setiap siklus penelitian terdiri dari dua pertemuan, Hasil penelitian menunjukkan bahwa hasil belajar siswa tuntas pada siklus I sebesar 68,75\% siswa dengan hasil rata-rata kelas sebesar 76,88 dan hasil belajar siswa tuntas pada siklus II sebesar $87,5 \%$ siswa dengan hasil rata rata kelas sebesar 86,9 . Dengan demikian pembelajaran dengan model project based learning berhasil meningkatkan hasil belajar siswa dalam mempelajari materi teknik penjarian recorder.
\end{abstract}

Kata Kunci: project based learning, seni budaya, hasil belajar, teknik penjarian recorder

\section{PENDAHULUAN}

Kesenian merupakan salah satu produk dari kebudayaan manusia, sebuah peradaban tumbuh dan berkembang dapat dilihat salah satunya dari kesenian yang berkembang pada masyarakat (Arifninetrirosa, 2005). Dengan demikian pemahaman mengenai kesenian perlu ditekankan kepada para pendidik senin agar pembelajaran senin menjadi lebih kontekstual.

Pada kurikulum 2013, siswa ditekankan untuk melakukan pembelajaran berbasis saintifik yaitu dengan menekankan siswa untuk dapat mengidentifikasi permasalahan yang ada, mencari informasi dan mengumpulkan informsi untuk memecahkan masalah dengan menggunakan langkah-langkah ilmiah (Malik, 2020). Melalui pembelajaran ini, siswa akan mampu mengembangkan pengetahuan dalam kehidupan dilingkungan mereka berada (Malik, 2020; Harosid, 2019).

Model Project Based Learning (PjBL) menekankan pada pembuatan proyek dari pembelajaran, guru memfasilitasi siswa untuk membuat proyek inovatif di kelas (Lestari, 2015). Model Project Based Learning (PjBL) memuat berbagai macam tugas yang kompleks yang milaui dari pertanyaan -atau pertanyaan yang menantang dan mengarahkan siswa untuk merancang, memecahkan permasalahan, mebuat keputusan, dan melakukan investigasi, serta mebuat peserta didik bekerja secara mandiri (Mahrawi, et al 2019).

Model Project-based Learning memiliki karakteristik pembelajaran yang menekankan peserta didik untuk diberikan masalah konkrit, selain itu di dalam pembelajarannya 
menekankan siswa untuk mencari solusi, dan pada prosesnya siswa diminta mengerjakan proyek di dalam tim untuk mengatasi permasalahan tersebut (Mahrawi, et al 2019). Adapun penailaian kinerja pada pembelajaran ini dapat dilakukan secara individu dengan melihat kualitas produk yang dibuat, kedalaman pemahaman siswa terhadap konten yang diperlihatkan, dan kontribusinya dalam tim (Mahrawi, et al 2019). Pembelajaran ini memungkinakan siswa untuk melakukan refleksi atas ide dan pendapat mereka serta membuat keputusan dalam membuat proyek, serta mempresentasikan hasil akhir dari produk yang mereka hasilkan (Mahrawi, et al 2019).

Purwanto (1996) mendefinisikan belajar sebagai suatu perubahan dalam kepribadian seseorang yang tercermin sebagai suatu pola baru baik berupa kecakapan maupun sebagai pengertian. Belajar menurut Prayitno (2009) diartikan sebagai suatu upaya untuk menguasai hal yang baru terdiri atas usaha untuk menguasai dan hasil yang diperoleh dari aktivitas belajar.

Berdasarkan hasil observasi di slah satu SMP Negeri di Kabupaten Bogor, Indonesia, pembelajaran Seni Budaya masih memerlukan perhatian khusus dengan melihat banyaknya siswa pada saat pembelajaran belum bisa mengapresiasi karya Seni Budaya dengan baik. Minimnya keterampilan tersebut dapat dilihat dari banyaknya siswa yang tidak paham Lagu Daerah Nusantara saat guru meminta mempraktikkan padahal pembelajaran tersebut sangat penting demi menjaga warisan kebudayaan lagu indonesia. Salain itu, ketuntasan pembelajaran Seni Budaya hanya tercapai ketuntasan 73,5. Pembelajaran seni budaya di dalam kurikulum 2013 untuk setiap kelas adalah tiga jam pembelajaran dalam satu minggu. Jika dilihat dari alokasi waktu dan materi yang terdapat pada mata pelajaran senin budaya, dapat dilihat pada perbandingan keduanya masih kurang proporsiaonal terlebih mata pelajaran senin budaya berorientasi pada praktek terlebih untuk mencapai kompetensi yang ada dengan standar kriteria ketuntasan minimal di sekolah tersebut sebesar 75. Dengan demikian, pengajar sebagai guru seni budaya harus menciptakan alternatif yang dilakukan untuk memberi penambahan jam pembelajaran seperti ekstrakulikuler. Dalam kegiatan ekstrakulikuler, untuk kegiatan pengembangan diri siswa dalam mengembangkan dan mengekspresikan diri siswa dapat menggunakan seni budaya. Dengan harapan, di sekolah tersebut dapat menggali keterampilan siswa melalui belajar seni budaya agar dapat bermanfaat untuk dirinya dan lingkungan sekitarnya. Keterampilan yang dimiliki siswa dapat dikembangkan secara optimal dalam bentuk karya-karya yang dapat dinikmati dirinya dan juga oleh orang lain. Lebih luas keterampilan psikomotorik yang dimiliki siswa melalui senin budaya dapat digunakan untuk meningkatkan kemampuan berwirausaha siswa. Dengan demikian untuk mencapai hasil belajar 
Jurnal Pendidikan Indonesia Gemilang, Vol 1, No.1, 2021, pp. 7-12

e-ISSN 2807-5285. DOI. 10.53889/jpig.v1i1.18

yang telah diuraikan diatas pendidik harus senantiasa mengembangkan proses pembelajaran yang lebih bermakna tentunya lebih berkualitas untuk mencapai hasil belajar yang lebih optimal.

Berdasarkan pada permasalahan yang telah dijelaskan, perlu dilakukan penelitian mengenai penerapanmodel pembelajaran project based learning untuk diuji keefektifitasannya dalam meningkatkan hasil belajar siswa pada materi teknik penjarian recorder pada pembelajaran Seni Budaya kelas IX.

\section{METODE}

Penelitian ini merupakan penelitian tindakan kelas (Arifin, 2012). Penelitian dilaksanakan di Kelas IX di salah satu SMP negeri di Kabupaten Bogor, Indonesia dengan mengambil sampel sebanyak 32 Siswa. Kelas yang dijadikan subjek peneltiian dalam penelitian ini merupakan siswa yang mempunyai nilai rapor dengan dengan kategori kurang baik. Penelitian ini menerapkan model project based learning untuk meningkatkan hasil belajar siswa pada materi teknik penjarian recorder pada pembelajaran seni budaya kelas IX.

\section{Perencanaan Tindakan}

Dalam penelitian ini, sebelum melakukan tindakan, maka dilakukan beberapa hal meluputi pembuatan Rencana Pelaksanaan Pembelajaran (RPP), peranrancangan skenario pelaksanaan tindakan, dan menyusun soal pretest dan posttest.

\section{Teknik Pengumpulan Data}

Teknik pengumpulan data dibatasi dengan penilaian hasil belajar siswa dalam belajar di Kelas IX di salah satu SMP Negeri di Kabupaten Bogor, Indonesia. Penilaian yang dilakukan dalam penelitian ini meliputi: 1) Absensi kehadiran siswa yang digunakan untuk menegakkan kedisplinan siswa masuk sekolah. 2) Membentuk Kelompok Bentuk penilaian dengan tujuan untuk menilai keaktifan siswa secara individu selama pembelajaran kelompok tentang materi mempelajari teknik penjarian recorder. 3) Melaksanakan praktikum penilaian awal untuk menguji ketrampilan siswa dalam melakukan tindakan nyata terhadap hasil implementasi model project based learning dengan mempelajari teori Seni Budaya yang dikompetisikan. 4) Mengadakan pretest. Nilai pretest adalah nilai untuk mengukur dasar pengetahuan siswa sebelum diadakan penelitian. Tindakan penilaian dilakukan dengan memberikan beberapa pertanyaan dengan rubrik hasil penilaian positif dan negatif. Penilaian tersebut berdasarkan komponen yang disusun untuk mengukur motivasi diri siswa dalam belajar.5) Mengadakan posttest. Nilai posttest adalah nilai untuk mengukur keberhasil keefektifan pembelajaran dengan model project based learning. 


\section{Teknik Analisis Data}

Untuk menghitung hasil pretest dan posttest menggunakan rumus berikut: (Purwanto, 2004).

$$
\mathrm{NP}=\frac{R}{S M} x 100
$$

Keterangan:

NP : Nilai persen yang dicari

R : Skor yang diperoleh peserta didik

SM : Skor maksimum

Indikator keberhasilan dalam penelitian ini adalah adanya peningkatan nilai tes dari siklus I ke siklus II dan ditunjukkan dengan pencapaian hasil nilai siswa dalam posttest. Tindakan penelitian dilakukan dengan indikator peningkatan hasil belajar pada materi teknik penjarian recorder yang ditunjukkan dengan pencapaian KKM yang besarnya 75 yang diperoleh oleh siswa sekurang-kurangnya $80 \%$ dari jumlah siswa yang dijadikan subjek penelitian.

\section{HASIL DAN PEMBAHASAN}

Penelitian dilakukan dengan menggunakan dua siklus, satu siklus terdiri dari dua pertemuan, supaya hasil penelitian dapat berjalan dengan sesuai rencana maka pelaksanaan dilakukan dengan pemberian resitasi penugasan dan beberapa protofolio instrumen penelitian. Tindakan Penelitian dilakukan sesuai dengan indikator yang sudah ditentukan dalam kurikulum 2013, dengan mengambil materi teknik penjarian recorder pada mata pelajaran seni budaya.

Berdasarkan hasil penelitian tindakan kelas dapat diketahui pembelajaran dengan model project based learning memberikan dampak keefektifan pembelajaran. Hal ini dapat dilihat pada peningkatan nilai individu siswa dari presentase ketuntasannya dalam mempelajari teknik penjarian recorder. Adapun pembahasan peningkatannya adalah sebagai berikut :

Hasil ketercapaian tindakan dengan project based learning di kelas yang dijadikan subjek penelitian tercapai dengan presentase ketuntasan 96,9\% dari 32 siswa dapat dilihat pada Tabel 2.

Tabel 2. Ketercapaian Hasil Belajar Kelompok Siswa

\begin{tabular}{lcc}
\hline Kriteria Penilaian & Siklus 1 & Siklus 2 \\
\hline Jumlah Rata-Rata & 76,88 & 87 \\
Siswa Tuntas & 22 & 28 \\
Siswa Tidak Tuntas & 10 & 4 \\
Presentase Ketercapaian (\%) & 68,75 & 88 \\
\hline
\end{tabular}


Hasil dari tugas kelompok dibagi menjadi 2 siklus, siklus 1 tugas praktikum tanpa sebelum diadakannya project based learning disiklus 1 dan yang ke 2 disiklus 2 setelah diadakannya project based learning. Peningkatan ini bisa dilihat dari hasil penilaian kelompok pada siklus 1 dari hasil presentase ketercapaian 68,75\% meningkat pada siklus 2 dengan presentase ketercapaian $88 \%$ sesuai dengan kategori aspek penilaian yang dikompetisikan dalam kelompok.

Penelitian tindakan kelas pada materi pelajaran Seni Budaya pada kelas IX menggunakan PjBL dapat meningkatkan hasil belajar siswa. Hasil penelitian ini sejalan dengan penelitian Mahrawi, et al (2019) yang juga melakukan penelitian pada konsep evolusi mengguunakan PjBL terhadap hasil belajar siswa dimana PjBL berpengaruh terhadap hasil belajar siswa yang dilihat dari hasil uji t. Selain itu, hasil penelitian ini menunjukkan bahwa terjadi peningkatan minat belajar siswa menggunakan PjBL. Hal ini sejalan dengan pendapat Setyowati \& Mawardi (2018) yang menyebutkan bahwa PjBL dapat meningkatkan minat belajar siswa. Kegiatan PjBL melibatkan siswa untuk berperan aktif di dalam pembelajaran. Sehingga dalam proses pembelajarannya siswa akan membagi perannya dalam menyelesaikan proyek yang diminta dalam proses pembelajarannya yang akan berdampak kepada siswa dalam meningkatkan hasil belajarnya. Permana \& Setyawan (2019) juga mengatakan bahwa PjBL merupakan pembelajaran yang kontekstual yang berpusat pada siswa. Sehingga akan membuat siswa menjadi lebih partisipatif dalam proses pembelajarannya dikarena mereka merasakan bahwa pembelajaran yang dilakukannya berhubungan dengan aktivitasnya di dalam kehidupan sehari-hari.

\section{KESIMPULAN}

Model project based learning dapat meningkatkan hasil belajar seni budaya siswa SMP kelas IX pada materi teknik penjarian recorder. Selanjutnya, bagi penelitian selanjutnya mengenai model pembelajaran PjBL perlu untuk memperhatikan waktu. Hal ini dikarenakan PjBL memakan waktu dalam proses mempraktikkan sehingga guru hendaknya memberikan jadwal khusus untuk pelaksanaannya

\section{DAFTAR PUSTAKA}

Arifin, Z. (2012). Penelitian Pendidikan Metode dan Paradigma Baru. PT Remaja Rosdakarya.

Arifninetrirosa. (2005). Pemeliharaan Kehidupan Budaya Kesenian Tradisional dalam Pembangunan Nasional. Jurnal USU Repository Universitas Sumatera Utara.

Harosid, H. (2019). Kurikulum 2013 Revisi 2017. 
Lestari, T. (2015). Peningkatan Hasil Belajar Kompetensi Dasar menyajikan Contoh Contoh Ilustrasi Dengan Model Pembelajaran Project Based Learning dan Metode Pembelajaran Demonstrasi Bagi Siswa Kelas XI Multimedia SMK Muhammadiyah Wonosari. Universitas Negeri Yogyakarta.

Mahrawi, M., Sari, I. J., Usman, U., Laila, F., Ningtiyas, N. A., \& Astrida, O. N. (2019, May). PENGARUH MODEL PEMBELAJARAN PROJECT BASED LEARNING (PjBL) TERHADAP HASIL BELAJAR PADA MATA KULIAH EVOLUSI. In Prosiding Seminar Nasional Pendidikan FKIP (Vol. 2, No. 1, pp. 61-66).

Malik, M. S. (2020). Analisis Materi Pokok SBdP MI/SD Kurikulum 2013 Abad 21. ELEMENTARY: Islamic Teacher Journal, 8(1), 59-82.

Nurfitriyanti, M. (2016). MODEL PEMBELAJARAN PROJECT BASED LEARNING TERHADAP KEMAMPUAN PEMECAHAN MASALAH MATEMATIKA. Jurnal Formatif, Vol 6(ISSN: 2088-351X), hal 149-160.

Permana, FH, \& Setyawan, D 2019, „Implementasi Mind Mapping Melalui Projet Based Learning untuk Meningkatkan Kemampuan Berpikir Kritis dan Hasil Belajar"e, Jurnal PIJAR MIPA, vol 14 no. 01, pp. 54-50

Prayitno. (2009). Dasar Teori dan Praksis Pendidikan. Grasindo.

Purwanto, N. (1996). Psikologi Pendidikan Remaja. Remaja Rosda Karya.

Purwanto, N. (2004). Prinsip-Prinsip dan Teknik Evaluasi Pengajaran. Rosdakarya.

Setyowati, N, \& Mawardi 2018, „Sinergi Project Based Learning dan Pembelajaran Bermakna untuk Meningkatkan Hasil Belajar Matematika ${ }^{e e}$, Jurnal Pendidikan dan Kebudayaan, vol. 08 no. 3, pp. $263-253$ 